\title{
GUIDELINES PROVIDED BY AVIATION REGULATORY AGENCIES AND ORGANIZATIONS DURING THE H1N1 AND COVID-19 OUTBREAKS: A COMPARATIVE ANALISYS
}

\section{ORIGINAL ARTICLE}

PACHECO, Aline ${ }^{1}, \mathrm{FAY}$, Claudia Musa ${ }^{2}$, HELMS, Henrique ${ }^{3}$, REDEL, Matheus Dall Agnol $^{4}$

PACHECO, Aline. Et al. Guidelines provided by aviation regulatory agencies and organizations during the H1N1 and COVID-19 outbreaks: a comparative analisys. Revista Científica Multidisciplinar Núcleo do Conhecimento. Year 06, Ed. 10, Vol. 07, pp. 148-178. October 2021. ISSN:2448-0959, Access link: https://www.nucleodoconhecimento.com.br/health/regulatory-agencies, DOI: 10.32749/nucleodoconhecimento.com.br/health/regulatory-agencies

\section{ABSTRACT}

Aviation has emerged as an additional and quicker vector for infectious diseases. Therefore, preparedness plans are put together to assist the public health and aviation sectors in a pandemic. This paper went through these preparedness plans, as well as the guidelines issued during two events, the H1N1 and COVID-19 pandemics, so to study, understand, assess and compare them. The method used was a thorough theoretical review supported by specific research questions, which are the basis for the analysis and discussion. The examination reveals consistent data which can work as a basis for measures of precaution and/ or mitigation of diseases.

Keywords: Disease outbreak, Pandemic, Regulatory agencies, Public health authorities, Aviation.

\footnotetext{
${ }^{1}$ Doctorate

${ }^{2}$ Doctorate.

${ }^{3}$ Doctorate.

${ }^{4}$ Bachelor.
} 


\section{INTRODUCTION}

Humanity has been through some horrible pandemics during its course of existence. The deadliest of them all, the Plague, also known as The Black Death, killed tens of millions of people across Europe, Asia and Northern Africa in the XIV Century (DEWITTE, 2014). Not too long ago, the Spanish Flu, caused by an Influenza A virus subtype $\mathrm{H} 1 \mathrm{~N} 1$, totaled an uncertain death toll that might have been as high as 50 million people and around 500 million people were infected by the virus (CDC, 2019). More recently, China saw the initial spread of a SARS-Cov outbreak in 2002, which lasted until 2004, causing 774 fatalities around 29 territories (WHO, 2003). In 2009, Mexico witnessed the start of a new pandemic caused by a new Influenza $A$ virus subtype H1N1, which then spread to most of the world, with the World Health Organization (WHO) putting the number of confirmed $\mathrm{H} 1 \mathrm{~N} 1$ deaths at a minimum of 18,499 people (WHO, 2011), although it is estimated that over 284,000 people have perished worldwide due to the Swine Flu (CDC, 2012). As of 2020, an extremely contagious new SARS-Cov virus has been responsible for a deadly outbreak that has increased the death toll up to 251,059 people (CSSE, 2020) in just over 4 months since the day the WHO was first notified of the existence of a pneumonia of unknown etiology in Wuhan, China, on December 31st, 2019.

Throughout the past and current centuries, aviation has improved a great deal. In 2019, for instance, the flight-tracking app FlightRadar24 (2021) tracked a record number of $68,948,849$ total flights. As aviation was increasingly powering the connectivity between countries, it also became an additional vector for the transmission of contagious communicable diseases (TATEM; ROGERS; HAY, 2006). Nowadays, the aviation sector must be properly advised on how to proceed with sanitary measures in airports and inside airplanes during a pandemic. International organizations, associations and national agencies issue fitting guidelines so that the aviation industry can abide and enforce them in order to halt the spread of a certain communicable disease. 
As important as airports and airlines are in forestalling the outbreak of a contagious communicable disease, they are also bound to have internal problems of their own regarding financial instability, lack of revenue and other expenses amidst a pandemic. In light of the current pandemic situation caused by the novel coronavirus, the world's economy has been plummeting and many countries are faced with serious economic recession scenarios. Like many other fields, the aviation industry is highly sensitive to economic downturns. Therefore, there also needs to exist some sort of economic guideline and recommendation for airlines and airports to follow in order to stave off as much as possible any utterly severe financial condition. In pandemic times, governments may very well impede the entry of foreign citizens and reduce the daily number of domestic flights, directly affecting the revenues of airports and airlines.

In the last 11 years, the world has seen two major pandemics caused by viruses: the H1N1 outbreak in 2009 and 2010 and the ongoing outbreak of COVID-19 in 2020. Pandemics have long been a part of humanity, and thus international health and aviation organizations as well as national agencies have to be able to learn from past experiences, build clear preparedness plans and also issue guidelines for the aviation industry to follow. As delicate as pandemic situations are, these preparedness plans and guidelines must be in accordance with each situation and must instruct airports and airlines with the best, most suitable courses of actions.

As the American journalist Derek Thompson stated in a recently published article on The Atlantic magazine, because the pandemic pauses the present, it forces us to live in the future (THOMPSON, 2020). For many, aviation is facing the worst crisis in history. The current drop in air travel is shockingly bigger than the ones after the terrorist attacks on September 11th, 2001 and during the Great Recession in 20082009 (ISIDORE, 2020). What happens now will directly affect the future of thousands of employers and employees in the aviation sector. As ruthless as pandemics are, they force us to ponder and warily assess how prepared the aviation industry actually was, what we could do to improve joint public health and aviation measures and to project ways to buoy the economy once again. 
Hence, this article aims to assess these guidelines and recommendations as they are so paramount to guide the airport industry in the right direction with the proper and correct procedures to be taken. Accordingly, the H1N1 and COVID-19 pandemics have been chosen as they provide a clear opportunity for reviewing the preparedness of States and organizations within the aviation sector upon impending outbreaks of communicable diseases, as well as to inspect what has changed guideline and preparedness-wise in a decade marked by the end of one pandemic and the start of a brand new and deadlier one. The article is intended to study, assess and compare the guidelines, measures and recommendations provided by regulatory agencies, organizations and associations to airport operators and airlines regarding economic issues and sanitary measures amidst the outbreaks of H1N1 in 2009/2010 and COVID-19 in 2020.

Therefore, the guidelines covered were the ones provided by international organizations and associations, such as the WHO and ICAO. Likewise, this paper aimed to conduct a specific analysis of the procedures suggested and/or demanded by Brazilian regulatory agencies.

This study targets the following:

a) to provide an outline of the $\mathrm{H} 1 \mathrm{~N} 1$ and COVID-19 pandemics through a chronological list of the most impactful events on aviation

b) to analyze the guidelines provided by the regulatory agencies and associations to airports and airlines amid the H1N1 pandemic with respect to economic actions and strategies;

c) to study the sanitary and health-related actions and procedures to be taken by airports and airlines during the outbreak of $\mathrm{H} 1 \mathrm{~N} 1$;

d) to carry out a historical retrospective of the period marked by the end of the $\mathrm{H} 1 \mathrm{~N} 1$ pandemic and the beginning of the COVID-19 pandemic in order to offer an overall 
account for possible precautionary measures that could be used in an attempt to mitigate contamination.

e) to assess the guidelines provided by the regulatory agencies and associations to airports and airlines during the COVID-19 pandemic regarding the recommendations on how to face an unprecedented economic debacle;

f) to address the sanitary and health-related actions and procedures to be taken by airports and airlines during the outbreak of COVID-19; and

g) to project the preparedness of the sectors studied for future outbreaks of infectious diseases.

In order to accomplish it, we chose to use a theoretical qualitative method of analysis. Firstly, we present a literature review of the biological aspects of both viruses, as well as travelling as a vector, enriched with the reading of as many online guidelines as possible so that the discussion could be made following a clear view of the preparedness and guidance scenario. These guidelines were then analyzed within the framework of four research questions, presented in the methodology section, namely: (1) how prepared were the agencies and organizations to face a pandemic?; (2) what were their recommendations?; (3) how did Brazilian national agencies act upon them?; and (4) what has been learned and/or improved in order to face future pandemics?. The answers to the questions are expected to provide fruitful ideas to the discussion, grasping a perspective of how prepared the aviation and public health sectors were prior to both pandemics, what has been learned since and how prepared they are now for impending outbreaks in the future, as they still strive to go through the deadly and ongoing COVID-19 pandemic. 


\section{LITERATURE REVIEW}

\subsection{AN OVERVIEW OF THE VIRUSES}

\subsubsection{INFLUENZA A (H1N1)}

In April 2009, a novel Influenza A (H1N1) virus of swine origin was identified as the cause of human infection and related acute respiratory illness in Mexico, which then spread to the United States and to most of the world's countries and overseas territories (WHO, 2010). Influenza A viruses are single stranded RNA viruses of negative sense with an eight segmented genome that belongs to the family Orthomyxoviridae (PEIRIS et al., 2009). They continually circulate in humans in yearly epidemics (mainly in the winter in temperate climates) and antigenically novel virus strains emerge sporadically as pandemic viruses (COX; SUBBARAO, 2000). An Influenza $A$ virus is made up of two envelope glycoproteins: viral haemagglutinin (HA) and neuraminidase (NA), which are considered antigens by human immune systems. These two proteins are used to subtype Influenza A viruses into $18 \mathrm{HA}$ and $11 \mathrm{NA}$, as of May 2020 (TONG et al., 2013). Aquatic birds are the main reservoir for influenza subtype viruses, although some subtypes have become established in other species, such as $\mathrm{H} 1$ and $\mathrm{H} 3$ in pigs, $\mathrm{H} 3$ and $\mathrm{H} 7$ in horses, equine $\mathrm{H} 3$ subtype in dogs (PEIRIS et al., 2009) and, more recently, H18 in Peruvian bats (TONG et al., 2013). It is believed that influenza pandemics happen when a novel avian influenza HA and/or NA is picked up through reassortment by human influenza virus that already existed, or by human-adapted entirely avian virus. Since pigs are susceptible to infection by avian and human virus strains and many reassortments have been isolated from pigs, they have been proposed as an intermediate host (TAUBENBERGER et al., 2006).

$\mathrm{H} 1 \mathrm{~N} 1$, also referred to as swine flu, is an upper respiratory tract disease and may cause inflammation of the upper respiratory passages and trachea, in addition to the lower respiratory tract, with an incubation period ranging from 1 to 4 days, averaging 2 days in most individuals. However, it could be up to 7 days in some individuals. The 
contagious period for adults is comprehended between the day prior to the symptoms appearance to as long as 7 days after the symptoms onset. Children and individuals with weakened immune systems may be susceptible to longer contagious periods (JILANI; JAMIL; SIDDIQUI, 2019).

\subsubsection{SARS-CoV-2}

Little over 10 years after the first $\mathrm{H} 1 \mathrm{~N} 1$ confirmed cases began to show up, the WHO became aware of a cluster of pneumonia cases in Wuhan, Hubei Province, China. Shortly after, it was revealed that a new type of coronavirus was being responsible for human-to-human transmissions, which was termed 2019-nCoV (WHO, 2020a). On February 11th, 2020, the WHO gave it a taxonomic designation "severe acute respiratory syndrome coronavirus 2" (SARS-CoV-2), which became the official means to refer to this virus strain (BAIG, 2020). Later on that same day, the WHO officially renamed the disease as COVID-19, which stands for coronavirus disease.

Coronaviruses are a large group of enveloped, positive single-strained large RNA viruses that not only affect humans, but also a wide variety of animals (VELAVAN; MEYER, 2020). The protein spikes on the envelope give it the appearance of a crown; and crown, in Latin, is called corona. There are several types of coronaviruses that cause respiratory and sometimes even gastrointestinal symptoms. However, there are some types of coronaviruses that can cause severe diseases, such as the SARS-CoV (Severe Acute Respiratory Syndrome coronavirus), first identified in China in 2002, and the MERS (Middle East Respiratory Syndrome), first identified in Saudia Arabia in 2012. There are four subfamilies, namely alpha-, beta-, gamma- and delta-coronaviruses, of which alpha- and beta-coronaviruses apparently originate from mammals, mainly bats, whilst gamma- and delta-viruses seem to originate from pigs and birds (VELAVAN; MEYER, 2020). For example, the MERS coronavirus is known to be transmitted from camels, whereas the SARS-CoV from civet cats (WHO AFRICA, 2020; PAHO, 2020). The beta-coronaviruses are known to be the most threatening among the seven subtypes of coronaviruses, leading to severe disease and fatalities. The SARS-CoV-2 virus belongs to the $B$ lineage of 
beta-coronaviruses and it has already been linked initially to a single local fish and wild animal market in Wuhan, although it is not confirmed yet (LAU et al., 2020; WHO, 2020b). It is, ipso facto, closely related to two bat-derived SARS-like coronaviruses, namely bat-SL-CoVZC45 and bat-SL-CoVZXC21 (88-89\% similarity), but only $79 \%$ similar to the SARS-CoV virus responsible for the SARS outbreak in 2002 (LAU et al., 2020), as there are key features that distinguish the two (GAO et al., 2020).

In line with a World Health Organization (WHO) report, 2019-nCoV is an unparalleled virus that causes respiratory disease. Transmission occurs via oral and nasal droplets - healthy people are also at risk of getting infected since the virus is able to float in the air in the form of aerosols (KOLIFARHOOD et al., 2020). The average incubation period was reported as 5 to 6 days, varying from 2 to 14 days.

COVID-19 and influenza diseases are quite similar in a sense of presentation, as they both cause respiratory complications. They both present a wide range of illness that goes from asymptomatic cases, through mild ones, and, in more severe cases, it can lead to death. In addition, both viruses can be transmitted by means of contact, droplets and fomites. Hence, essentially the same public health measures may be taken or at most adapted in order to prevent infection, such as hand hygiene. Notwithstanding the similarities, there are plenty differences as well. The number of secondary infections spawned from one infected individual seems to be between 2 and 2.5 for COVID-19 virus, higher than for influenza. However, comparison between the two viruses and the respective diseases should be coupled with the knowledge that they are very circumstance and time-specific (WHO, 2020b).

For COVID-19, data to date, as of March 17th, 2020, indicate that $80 \%$ of infections are mild or asymptomatic; $15 \%$ are severe infection, requiring oxygen; and $5 \%$ are critical infections, requiring ventilation. These percentages of severe and critical infection would be greater than what is observed for influenza infection. Individuals prone to severe influenza differ from COVID-19 - the latter seems to be more harmful to older people and to individuals with comorbidities, when the former impairs 
children, pregnant women, elderly, those with comorbidities and those who are immunosuppressed (WHO, 2020b).

\subsection{TRAVELLING AS A VECTOR}

Travel is a powerful force in disease spread. Migration of humans has been the pathway for disseminating infectious diseases throughout recorded history (WILSON, 1995). Infectious diseases that began to affect indigenous populations in Africa, North and South America and the Pacific can be linked to the European colonization of these territories (INGOLD, 1994). Commercial and trade routes were absolutely key for the spread of the bubonic plague through Asia, Europe and the Mediterranean in the XIV Century (COSSAR, 1994; HELMS, 2018). Human mobility, travel and migration will invariably continue to shape the emergence, frequency, and spread of infections in geographic areas and populations. The current volume, speed, and reach of travel are unprecedented, though (WILSON, 1995).

Unlike past epidemics and pandemics in human history prior to aviation development and growth, where the diseases could only travel as fast as humans could walk, ride their horses or sail their boats and ships (TATEM; ROGERS; HAY, 2006), nowadays it is perfectly possible for a passenger to acquire a disease and travel to virtually anywhere in the world within 1 to 2 days. It is important to bear in mind that diseases powered by air travel can be of various types - cholera and tuberculosis, for instance, are caused by bacteria; dengue, Chikungunya, Zika and Malaria, by arboviruses; Influenza A by influenza viruses; MERS and SARS by coronaviruses. Thus, infectious diseases disseminated by air travel may be scattered or even sporadic and have little potential for further transmission (FINDLATER; BOGOCH, 2018; REZZA, 2018; FISCHER; STAPLES, 2014).

As previously featured in Helms (2018), aviation can be a vector in disease spread as it speeds up the process regarding how fast certain diseases reach different parts of the world. The necessity to travel to farther regions, more and more frequently has continuously boosted the aeronautical sector. Larger aircraft, more places been 
accessed, more operational technology impact the amount of people travelling and, as a consequence, more spread in diseases.

Travelling has also shown how fast pulmonary infections can be transmitted. Data suggest that the risk of transmission to an assymptomatic passenger inside an aircraft cabin can be associated to sitting within the distance of two rows from an infected passenger for longer than eight hours. This association is mainly derived from investigations on the in-flight transmission of tuberculosis. Cabin ventilation in the cabin is seen as a factor that allows for disease spread (TRIMBLE; MOFFAT; COLLINS, 2017).

The epidemiological vulnerability in the XXI Century, induced by a closely inter and air-connected world, has been illustrated by two main outbreaks: SARS, in 20022003, when a SARS-CoV virus quickly spread from East Asia to 25 other countries (BUDD; BELL; BROWN, 2009; BOWEN; LAROE, 2006), and the Influenza a H1N1 in 2009. Bowen and Laroe (2006) state that a crucial feature of the transmission of SARS that greatly facilitated the global containment of the disease is that patients are infectious only after they exhibit symptoms. In 2020 the world is seeing a deadly pandemic of COVID-19, caused by a SARS-like virus, which has accounted for 109206497 cases (in accordance with the applied case definitions and testing strategies in the affected countries), since 31 December 2019 and as of week 20216, including 2407469 deaths (ECDC, 2021).

The main existing rules that conduct airlines and airports procedures during an outbreak of a communicable disease derive from both the WHO and ICAO, which are United Nations specialized agencies responsible for spearheading the effort to halt the outbreaks of such diseases worldwide. In fact, ICAO is the main body in the sense that it is responsible, according to Article 14 of the 1944 Convention on International Civil Aviation, to oblige Contracting States "to take effective measures to prevent the spread by means of air navigation of cholera, typhus (epidemic), smallpox, yellow fever, plague, and such other communicable diseases as the Contracting States shall from time to time decide to designate" (FERRELL; AGARWAL, 2018, p. 3). A contracting state means a state which has consented to 
be bound by the treaty, whether or not the treaty has entered into force; (VIENNA CONVENTION ON THE LAW OF TREATIES, 1969, p. 3). To that end, ICAO issues technical guidelines and develops preparedness plans in accordance with the International Health Regulations, 2005 (IHR; WHO, 2005), whose function and scope are to "prevent, protect against, control and provide a public health response to the international spread of disease in ways that are commensurate with and restricted to public health risks, and which avoid unnecessary interference with international traffic and trade" (FERRELL; AGARWAL, 2018; IHR, 2005). From this point on, each disease outbreak may have its own set of guidelines and future preparedness planning based on its own singularities and the needs imposed by them.

As a matter of fact, the responsibility to coordinate, share knowledge and act upon emerging epidemics rests not only with ICAO and WHO, but also with all civil aviation authorities, public health authorities and every party involved in the aviation sector, such as airlines and airports. In 2006, a new tool was created in order to coordinate the international aviation response to public health risks, such as pandemics: CAPSCA, short for Collaborative Arrangement for the Prevention and management of public health events in Civil Aviation (ICAO, 2015). It is a joint, global and collaborative arrangement established between international organizations, including ICAO, WHO, United Nations World Tourism Organization (UNWTO), International Air Transport Association (IATA) and Airports Council International (ACl) that aims to improve preparedness planning in States in the aviation sector for public health emergencies, or potential emergencies, that can arise from communicable disease outbreaks (ICAO, 2015). CAPSCA website served as a hub for this research as it gathered on a single place links to all international organizations that were studied.

\subsection{A HISTORICAL RETROSPECTIVE FROM THE H1N1 TO THE COVID-19 PANDEMIC}

The core of this research is a historical retrospective made from the start of the Influenza A pandemic in 2009 through to the current COVID-19 pandemic. The guidelines and recommendations issued for airports and airlines throughout the 
H1N1 pandemic in 2009 and 2010 were read along with preparedness plans and regulations, such as the International Health Regulations from 2005.

As for the time between the outbreaks of H1N1 and COVID-19, an analysis was conducted to inspect whether regulations and guidelines had changed in order to better respond to future epidemics. This gradually led to the COVID-19 outbreak in 2020 .

First and foremost, pandemic influenza phases were first classified in 1999 by the WHO in order to distinguish levels of risk and necessary government responses. Then, in 2005, these phases were revised, and some considerable changes were made (WHO, 2005). The phases are suited for the confection of a global framework that can assist countries in pandemic preparedness and response planning. With the $\mathrm{H} 1 \mathrm{~N} 1$ pandemic in 2009, a new revision was issued, which consisted of studies that had begun in 2007. These phases can be briefly defined as the following: phases 1-3 portray a scenario in which there are predominantly animal infections, with few human infections; phase 4 is defined by sustained human-to-human transmission; in phase 5 , human-to-human spread of the virus into at least two countries in one WHO region is confirmed; phase 6 , the pandemic phase, begins when community level outbreaks in at least one other country in a different WHO region is acknowledged, in addition to the criteria stated in Phase 5; and unlike past revisions, post peak and post pandemic phases were added, which stand for possibility of recurrent events and disease activity at seasonal levels, respectively (WHO, 2009). As of August 1st, 2010, worldwide more than 214 countries and overseas territories or communities reported laboratory-confirmed cases of pandemic influenza H1N1 2009, including over 18,449 deaths (WHO, 2011).

On April 25th, 2009, the WHO announced a Public Health Emergency of International Concern, known as PHEIC, due to a novel influenza $A$ (H1N1) virus. PHEIC is defined, per the IHR 2005, as an extraordinary event that (1) constitutes a public health risk to other States through the international spread of disease and (2) to potentially require a coordinated international response (IHR, 2005). The rapid spread of the virus posed a serious risk of a pandemic. Just as expected, on June 
11th, 2009, the WHO declared an influenza pandemic (phase 6) was in progress (WHO, 2011).

As mentioned before, WHO and ICAO serve as hubs for information, guidelines and recommendations so as to assist airports and airlines in taking the fundamental procedures to fend off the risk of a wider spread of an infectious disease. Amidst the Influenza A (H1N1) pandemic, it was no different.

What stands out during every pandemic is that these international bodies issue mostly guidelines and recommendations. They frequently advise following procedures of published regulations, such as the IHR 2005 and other advisories on public hygiene, and do not tell in practical terms what national aviation and public health authorities as well as airports and airlines should do. That leads to another grave problem: world's inequality, as well as shaky politics and poor infrastructure of many countries.

Consequently, the enforcement of measures and procedures concerning air transport ultimately rests with national public authorities, airlines and airports. As published on ACl's airport preparedness guidelines for outbreaks of communicable disease, the responsibility for management of the risk of communicable diseases at airports rests primarily with the local/regional/national public health authority and the relevant airport operator (ACI, 2020).

Table 1 - Timeline of the H1N1 epidemic

\begin{tabular}{|l|l|}
\hline $18 / 03 / 2009$ & $\begin{array}{l}\text { Mexico began to pick up cases of what would later be identified } \\
\text { as the swine flu. }\end{array}$ \\
\hline $28 / 03 / 2009$ & Earliest onset date of H1N1 in the United States. \\
\hline $13 / 04 / 2009$ & $\begin{array}{l}\text { A woman died of H1N1 in Oaxaca, Mexico. This is the first H1N1- } \\
\text { related death worldwide. }\end{array}$ \\
\hline $25 / 04 / 2009$ & $\begin{array}{l}\text { The WHO declared a "Public Health Emergency of International } \\
\text { Concern", known as PHEIC. }\end{array}$ \\
\hline $26 / 04 / 2009$ & \begin{tabular}{l}
2009 H1N1 was declared a Public Health Emergency in the US. \\
\hline
\end{tabular}
\end{tabular}


Audible warnings began to be broadcasted in five major Brazilian airports, all of which received regular flights from Mexico and the United States. Screening of passengers arriving from these places was also implemented in these airports.

27/04/2009 WHO Director-General raised the level of influenza pandemic alert from phase 3 to phase 4, based on data showing person-to-person spread and the ability of the virus to cause community-level outbreaks. The 2nd Meeting of the IHR Emergency Committee was held to review data - based on the advice of the Committee, the WHO directorgeneral recommended (1) not to close borders, (2) not to restrict international travel, (3) people who are ill to delay international travel and (4) people developing symptoms following international travel to seek medical attention.

29/04/2009 WHO raised the level of influenza pandemic alert from phase 4 to phase 5 , meaning that a pandemic was imminent, and requested all countries to put their preparedness plans in action. Nine countries have reported 148 official cases of $\mathrm{H} 1 \mathrm{~N} 1$.

30/04/2009 IATA emphasized that airlines are prepared for the heightened level of alert following the World Health Organization's (WHO) decision to move to Phase 5 of its pandemic preparedness plan, stating that it has worked with WHO to prepare guidance materials for front line staff at airlines, including cabin crew, maintenance workers, cleaners, passenger agents and cargo/baggage handlers.

01/05/2009 11 countries have officially reported 331 cases of influenza A (H1N1) infection.

06/05/2009 In the ACl's World Report of May 2009, the H1N1 outbreak was once again greatly addressed. Three main notes from the $\mathrm{ACl}$ in this report: (1) no rationale for travel restrictions, as stated by the WHO, (2) checks on arriving passengers at airports are not considered efficient in stopping the spread of the disease and (3) the raising by the WHO of the influenza pandemic alert level to phase 5 reflects the geographic 


\begin{tabular}{|c|c|}
\hline & spread of the disease, not its severity. \\
\hline 07/05/2009 & Brazil officially reported the first confirmed cases of H1N1. \\
\hline 16/07/2009 & $\begin{array}{l}\text { Sustained transmission of H1N1 was declared in Brazil. Up until this } \\
\text { day, ANVISA had been working on actions to face the pandemic in } \\
\text { Brazil, according to its phases, and helped to organize the Brazilian } \\
\text { Influenza Pandemic Preparedness Plan. }\end{array}$ \\
\hline $01 / 11 / 2009$ & $\begin{array}{l}\text { The WHO said that worldwide more than } 199 \text { countries and overseas } \\
\text { territories/communities have reported laboratory confirmed cases of } \\
\text { pandemic influenza } \mathrm{H} 1 \mathrm{~N} 12009 \text {, including over } 6000 \text { deaths. }\end{array}$ \\
\hline 27/12/2009 & $\begin{array}{l}\text { The WHO said that over than } 208 \text { countries, territories and } \\
\text { communities have reported H1N1 cases, including "at least" } 12,220 \\
\text { deaths. }\end{array}$ \\
\hline $25 / 01 / 2010$ & $\begin{array}{l}\text { The protocol for handling pandemic influenza in ports, airports and } \\
\text { borders in Brazil was updated. }\end{array}$ \\
\hline $11 / 08 / 2010$ & The WHO announced the end of $2009 \mathrm{H} 1 \mathrm{~N} 1$ influenza pandemic. \\
\hline
\end{tabular}

Source: Elaborated by the authors based on documents from World Health Organization (WHO), International Civil Aviation Organization (IATA) data.

\subsection{THE COVID-19 PANDEMIC}

Similar to the H1N1 study, as many guidelines and recommendations as possible were read concerning the COVID-19 pandemic. Special attention was given to any updates on these regulations or any change of epidemic response approaches. To better understand the events that have happened so far, a timeline for the COVID-19 pandemic was organized. It begins with the first reports of pneumonia cases of unknown cause in the Chinese city of Wuhan. Therefore, all events depicted took place in the timespan between December 31st, 2019 and February 1st, 2021. This timeline is shown below. 
Table 2 - Timeline of the SARS COVID 19 pandemic

\begin{tabular}{|c|c|}
\hline 31/12/2019 & $\begin{array}{l}\text { The WHO is informed by Chinese authorities of a cluster of pneumonia cases of unknown } \\
\text { cause in Wuhan, Hubei Province, China. }\end{array}$ \\
\hline 30/01/2020 & $\begin{array}{l}\text { WHO declares the novel coronavirus outbreak a public health emergency of international } \\
\text { concern (PHEIC). ICAO releases an electronic bulletin on ongoing developments regarding } \\
\text { the coronavirus outbreak after the WHO declared a PHEIC. }\end{array}$ \\
\hline $01 / 02 / 2020$ & $\begin{array}{l}\text { The National Agency of Sanitary Surveillance of Brazil (ANVISA) releases a technical } \\
\text { note ( } \mathrm{N}^{\circ} 38 \text { ) laying out the sanitary measures to be taken at points of entry in relation to the } \\
\text { COVID-19 outbreak. }\end{array}$ \\
\hline $03 / 02 / 2020$ & $\begin{array}{l}\text { WHO releases the international community's Strategic Preparedness and Response Plan to } \\
\text { help protect states with weaker health systems. Brazil declares a Public Health Emergency } \\
\text { of National Concern. }\end{array}$ \\
\hline $13 / 02 / 2020$ & $\begin{array}{l}\text { ICAO issues a State Letter referring to State support to prevent the spread of Novel } \\
\text { Coronavirus Disease (COVID-19). }\end{array}$ \\
\hline $14 / 02 / 2020$ & $\begin{array}{l}\text { ANVISA provides recommendations for airport operators in Brazil concerning the } \\
\text { COVID-19 outbreak. }\end{array}$ \\
\hline $26 / 02 / 2020$ & Brazil confirms its first case of COVID-19. \\
\hline $28 / 02 / 2020$ & WHO raises the global risk of spread of COVID-19 from "high" to "very high". \\
\hline $06 / 03 / 2020$ & ICAO and WHO issue a joint statement on the outbreak of COVID-19. \\
\hline $08 / 03 / 2020$ & Over 100 countries report cases of COVID- 19. \\
\hline $11 / 03 / 2020$ & $\begin{array}{l}\text { WHO's Director-General declares the global COVID-19 outbreak a pandemic. } 118,319 \\
\text { confirmed cases worldwide, including 4,292 deaths. }\end{array}$ \\
\hline $13 / 03 / 2020$ & $\begin{array}{l}\text { "Europe has now become the epicenter of the pandemic, with more reported cases and } \\
\text { deaths than the rest of the world combined, apart from China", says the WHO Director- } \\
\text { General. }\end{array}$ \\
\hline $17 / 03 / 2020$ & $\begin{array}{l}\text { Brazil confirms its first COVID-19 death - a 62-year-old male in São Paulo. ACI World } \\
\text { urges a global temporary suspension of airport slot requirements and says that support for } \\
\text { the aviation industry must not discriminate. }\end{array}$ \\
\hline $18 / 03 / 2020$ & $\begin{array}{l}\text { WHO issues an interim guidance on operational considerations for managing COVID-19 } \\
\text { cases or outbreak in aviation. ACI World proposes a global policy response to COVID-19 } \\
\text { pandemic. The following policy measures were recommended by the Council: (1) } \\
\text { protection of airport revenues, (2) alleviation of airport slots usage requirements, (3) } \\
\text { concession fee payments to governments, (4) tax relief for the aviation sector and (5) } \\
\text { government assistance. In Brazil, provisional measure } \mathrm{N}^{\circ} 925 \text { is issued regarding } \\
\text { emergency measures for the Brazilian civil aviation in light of the COVID-19 pandemic. }\end{array}$ \\
\hline $12 / 05 / 2020$ & $\begin{array}{l}\text { ICAO establishes the Task Force on Health Issues Outbreaks in Aviation. The document } \\
\text { states that "The mandate of the Task Force is to review and update, as required, existing } \\
\text { 'healthrelated' Standards and Recommended Practices (SARPs) of Annex } 9-\text { Facilitation } \\
\text { to the Convention on International Civil Aviation and related guidance material, as well as } \\
\text { to recommend the adoption of new SARPs as deemed necessary". }\end{array}$ \\
\hline $27 / 05 / 2020$ & $\begin{array}{l}\text { ICAO, in cooperation with IATA and ACI, launches CART: Council Aviation Recovery } \\
\text { Task Force, a guidance for air travel through the COVID-19 public health crisis. The CART } \\
\text { Take-off guidance includes a section on Public Health Risk Mitigation Measures, in addition } \\
\text { to four operational modules relating to (1) airport guidelines, (2) aircraft guidelines, (3) crew } \\
\text { guidelines and (4) cargo guidelines. } \\
\text { ACI World issues new guidance for airport industry restart and recovery. }\end{array}$ \\
\hline
\end{tabular}




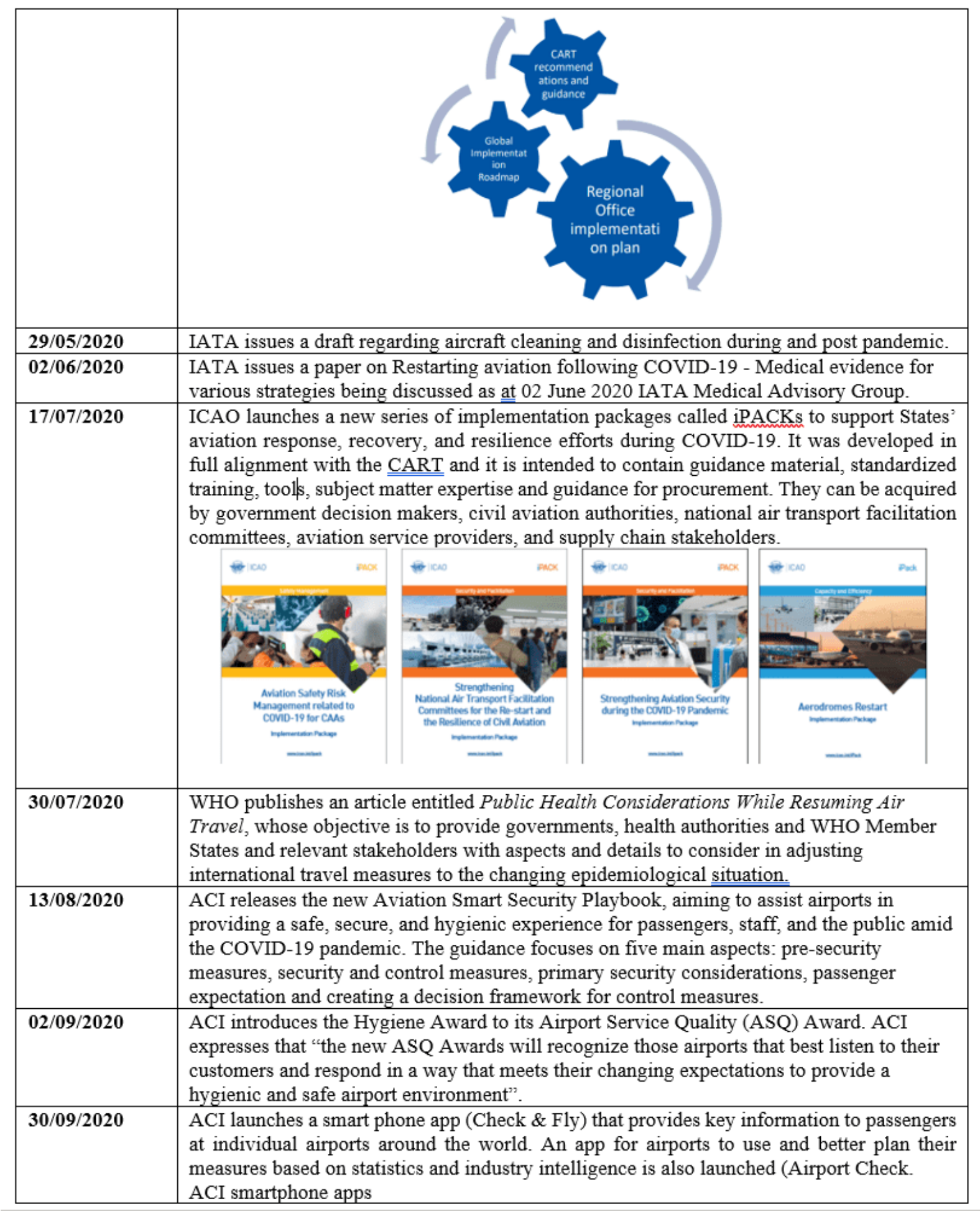




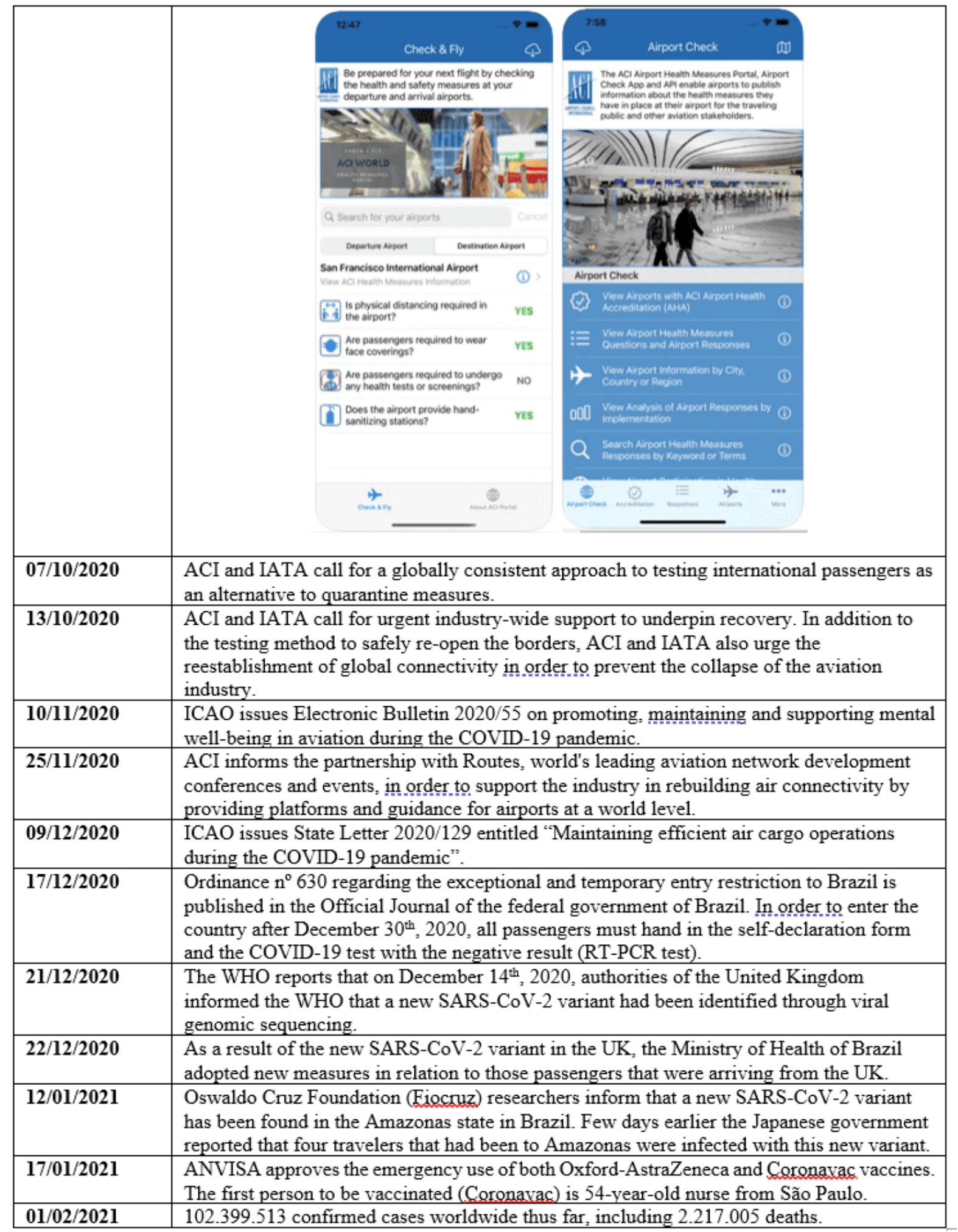

Source: Elaborated by the authors based on documents from World Health

Organization (WHO), International Civil Aviation Organization (ICAO), International 
Civil Aviation Organization (IATA), National Civil Aviation Agency of Brazil (Anac), Airports Council International (ACI) and App Store (2021).

\section{METHODOLOGY}

This study is mainly based on the written guidelines, procedures and recommendations provided by the following regulatory agencies and organizations:

h) World Health Organization (WHO);

i) International Civil Aviation Organization (ICAO);

j) International Air Transport Association (IATA);

k) Airports Council International (ACl);

I) Ministry of Health of Brazil;

m) National Civil Aviation Agency of Brazil (Anac); and

n) Brazilian Health Regulatory Agency (ANVISA).

Through the study conducted, it is possible to grasp a pecking order of those regulatory agencies and international organizations listed above. Firstly, the WHO and ICAO, both United Nations specialized agencies, issue guidelines and recommendations globally, so that national agencies can abide by them. International organizations - represented here by IATA and $\mathrm{ACl}$ - issue guidelines and recommendations as well for their respective public. Notably, most of these guidelines refer to the $\mathrm{WHO}$ and ICAO themselves. Therefore, one passing through IATA and ACl's guidelines frequently finds oneself being redirected to WHO and ICAO's documents concerning a certain pandemic or the preparedness plans for future ones. Last but certainly not least, national agencies are the ultimate form of action when dealing with health measures in aviation during a pandemic. Since ICAO, IATA and ACI issue guidelines and orientations rather than specific measures per se to be taken, national agencies usually find themselves in a spot to elaborate 
plans to face the epidemic in the country's ports of entry; in the case of this study, airports.

Figure 1 - Regulatory Agencies and Organizations Chart

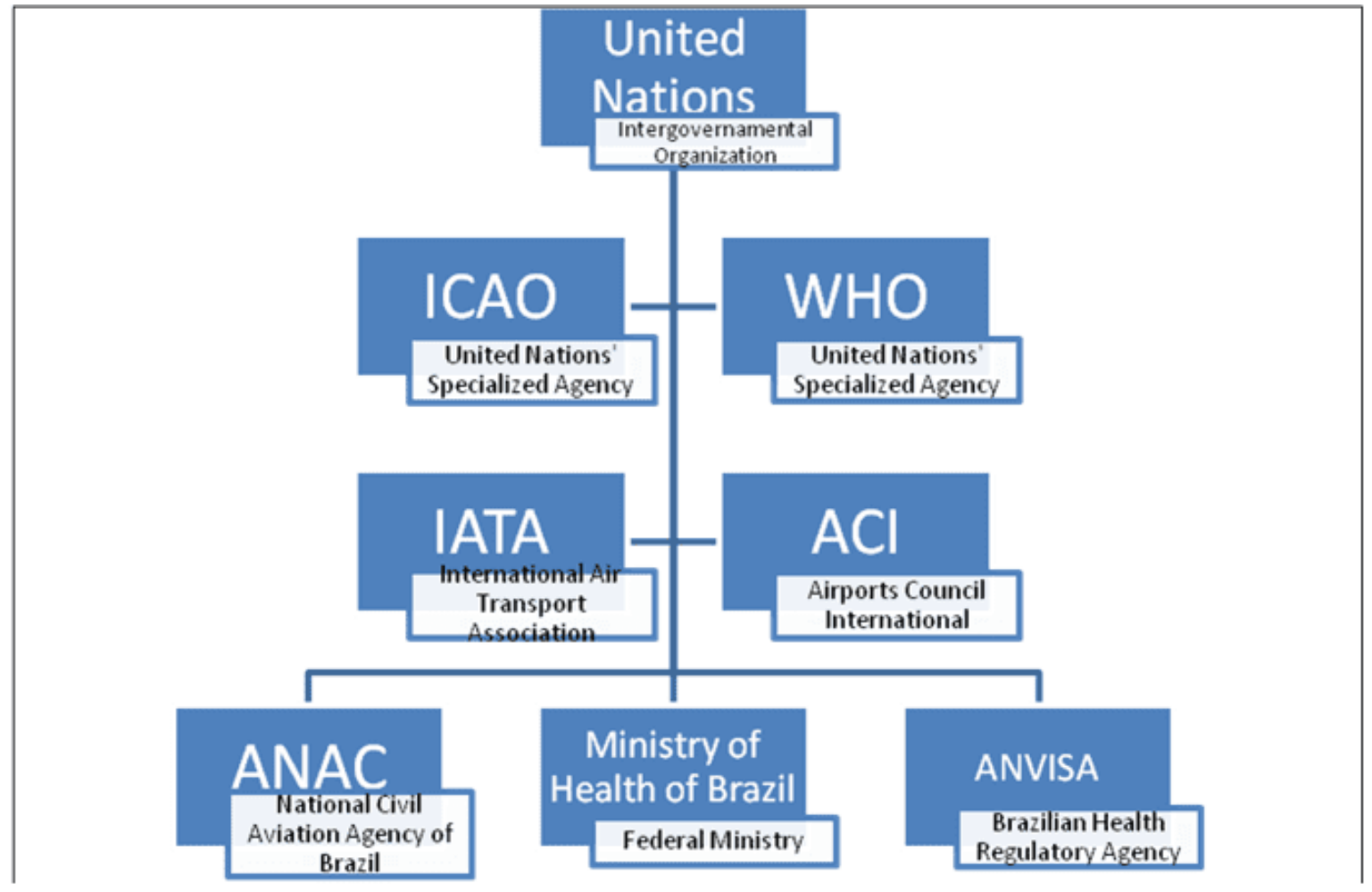

Source: The Authors (2020).

A qualitative research was carried out in order to analyze, comprehend and evaluate all guidelines provided by the organizations and agencies mentioned above. The number of organizations studied was previously defined in order to delimit a line of research and to increase the quality of the study. The main means of communication used by international organizations and national agencies are their own websites; therefore, this research mainly fed from the guidelines issued online by these agencies.

The timespan for the COVID-19 pandemic concerning this study goes from the very start of it to September 2020. The guidelines and recommendations studied are all from this period. As for the $\mathrm{H} 1 \mathrm{~N} 1$ outbreak, the whole pandemic period is taken under consideration.

$\mathrm{RC}: 99838$

Available in: https://www.nucleodoconhecimento.com.br/health/regulatory-agencies 
The guidelines and recommendations were analyzed and assessed based upon four main research questions:

a) how prepared were these agencies and organizations to face a pandemic?

b) what were their recommendations?

c) how did Brazilian national agencies act upon them?

d) what has been learned and/or improved in order to face future pandemics?

\section{ANALYSIS AND DISCUSSION}

\subsection{HOW PREPARED WERE THESE AGENCIES AND ORGANIZATIONS TO FACE A PANDEMIC?}

When there is a chronological spacing from a certain event, it becomes way easier to spot any attitudes, approaches or mindsets that could have - or should have - been different. In aviation, accidents show us the faulty points that must be improved so that the chances of a new, similar one happening are reduced. Fortunately, the aviation industry is a true reference in doing this. With regard to epidemic/pandemic preparedness plans, it is analogous.

Four years prior to the onset for the $\mathrm{H} 1 \mathrm{~N} 1$ outbreak, the International Health Regulations (IHR 2005) were adopted by the fifty-eighth World Health Assembly, and came into force two years later, in 2007. This document gathers crucial instruction regarding public health response to the international spread of diseases - whereby it has become a pivotal handbook for guiding public health parties in the safest, most suitable courses of action during the outbreak of infectious diseases. About the IHR, two relevant points ought to be stressed: (1) it covers for non-specific diseases, which means that it could be used for years to come and (2) it avoids unnecessary interference with international traffic. 
Figure 2 - IHR as a Public Health Good

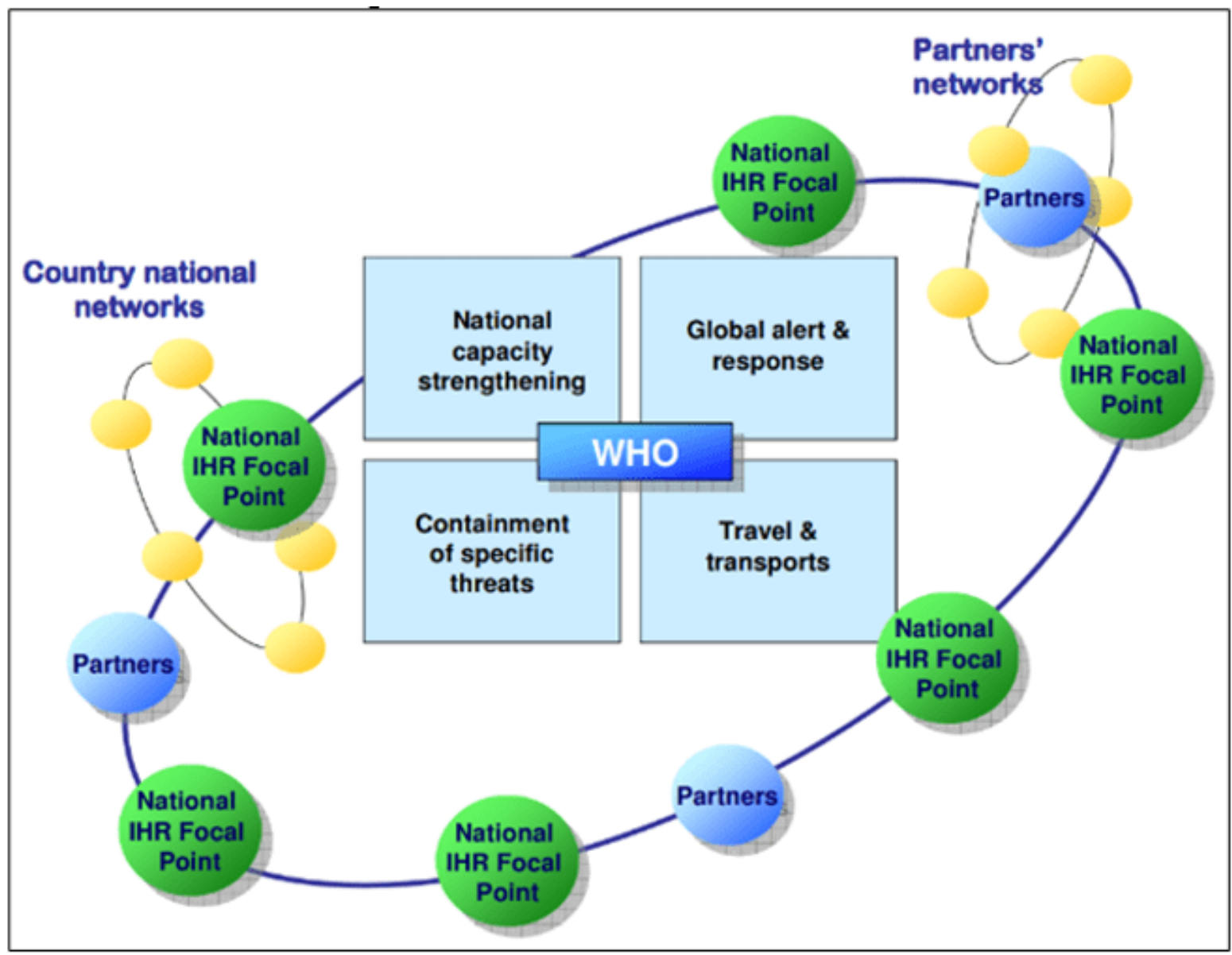

Source: WHO (2014).

As the aviation sector was steadily growing since the IHR were first adopted in 1969, with its natural ups and downs, several outbreaks of various diseases helped to strengthen the preparedness of public health and aviation agents on how to deal with the international spread of such diseases. When the H1N1 pandemic came, they were prepared - prepared with what had been learnt so far. There had already been other influenza pandemics in the past, which also helped the global community to take action against the H1N1 outbreak. The screening practice at airports had long been a known method of safety measure, as seen on the SARS outbreak in the beginning of this century. The efficacy of this method is arguable, though. In a study conducted on Narita International Airport, in Tokyo, during the H1N1 pandemic, as low as $22.2 \%$ among the confirmed cases had fever identified by the thermoscanner, 
and $55.6 \%$ of confirmed cases were taking medication to reduce fever (NISHIURA; KAMIYA, 2011). Therefore, screening alone can be somewhat of a misguided attempt to halt international spread of influenza. An article published by the WHO says that the interventions to mitigate the spread of infectious diseases would have a potentially heftier impact if implemented as close as possible to the source of the epidemic threat (KHAN et al., 2013).

One thing to ponder before jumping to any conclusions when comparing the preparedness of the aviation sector for the H1N1 and COVID-19 pandemics is that the world has become way more technological during the past 10 years. In 2009, the world was already technology-dependent; nowadays, even more so. As the international organizations, government bodies, airlines and airports made themselves more and more present on the web, online guidelines, instruction packs and even webinars became more common therefrom.

During the 2010s, different parts of the world experienced several disease outbreaks, such as MERS, dengue, chikungunya, Ebola and Zika, just to name a few. From each and every one of these outbreaks, something useful was learnt aviation-wise. Distinct ways of controlling the spread of a disease by reason of different viruses, preparedness plans previously put together, among other points contributed to a state of alertness to the new possible epidemic. However, when a merciless virus suddenly hits, it sets the world on action mode in a matter of weeks. There are two distinct moments when dealing with a pandemic threat: avoidance/preparedness and, then, action, for which there is a very fine line that separates them. Being $100 \%$ ready for a pandemic is somehow utopian, considering that there is no way of knowing which virus or bacteria will hit next.

The COVID-19 pandemic came up as a relentless one, spreading from China to the other continents very quickly. When the pandemic hit hard, airlines and airports started to have severe financial issues of their own, all of which amidst the stern sanitary protocols they were required to follow closely. When the world is faced with a deadly virus, government's travel restrictions and screening measures are put into effect. When dealing with a situation as global as a pandemic, and even though 193 
countries are ICAO Contracting States (ICAO, 2019), it is invariable that politics is going to be a part of the picture and thus hinder the optimal adherence to the settled action plans against international spread of a disease.

In short, there is not an exact technique or scale to measure the preparedness of an entire sector; however, it is conceivable to say that aviation and public health authorities were prepared with what had been learnt so far, with numerous preparedness plans hammered out and, as the outbreak evolved, adjustments were bound to be made. Dealing with a pandemic and its forthcoming effects is something that takes previous knowledge into consideration as well as clear-cut adjustments and improvements where they are needed.

\subsection{WHAT WERE THEIR RECOMMENDATIONS?}

Concerning the H1N1 pandemic, the WHO issued technical guidance and recommendations to the aviation sector, many of which were developed in cooperation with ICAO. In fact, throughout the pandemic, travel restrictions were not encouraged by the WHO - since the virus had already spread worldwide, the focus shifted to minimizing the impact of the virus rather than stopping its spread internationally. Those sorts of measures were validated by historical records of success on previous influenza pandemics, as well as the SARS outbreak in 20022003 (WHO, 2009; BOWEN; LAROE, 2006).

One of the main ICAO documents regarding the pandemic was a contingency plan that was issued by the agency in May 2009. Basically, ICAO reinforced the WHO recommendation that advised travel restrictions were not warranted, as they would have little effect on stopping the virus from spreading but would be highly disruptive to the global community (ICAO, 2009). Furthermore, in this document ICAO refers solely to the 1944 Civil Aviation Convention, the IHR 2005 and CAPSCA, through which Contracting States should primarily: (1) ensure that air transport services remain uninterrupted; (2) take account of additional guidance material issued by ICAO and facilitate the exchange of relevant information between airport and aircraft operators and public health authorities; (3) comply with the IHR 2005 and the WHO's 
recommendations and advice issued with regard to this outbreak and; (4) if those Contracting States which are considering introduction of health measures in addition to those recommended by WHO shall do so in accordance with the IHR 2005 (ICAO, 2009).

As for the COVID-19 pandemic, several guidance packs had already been built from the experience of previous communicable disease outbreaks. Throughout this pandemic, numerous bulletins, guidelines, protocols and other sorts of instruction documents were issued. Based on the massive number of guidance documents available online, meticulous remarks on each one of them would make this article incredibly extensive; wherefore it is viable to say that the majority of these documents were issued intending to (1) provide the most accurate and updated information as possible, (2) endorse and promote global cooperation in order to halt the international spread of COVID-19 and (3) to avoid any unnecessary meddling on air travel. As the COVID-19 outbreak continues to unfold, updated guidance keeps being released, as well as plans for the sector's rebuilding following an implacable sanitary and economic crisis.

\subsection{HOW DID BRAZILIAN NATIONAL AGENCIES ACT UPON THEM?}

Respecting the H1N1 outbreak, in Brazil the Ministry of Health reaffirmed the WHO recommendation that there was no need for any travel restrictions whatsoever. The Ministry oriented travelers that were arriving from pandemic affected countries to seek medical assistance should they begin to have symptoms up to ten days after the arrival. In short, the National Civil Aviation Agency of Brazil (ANAC) became responsible for working alongside the Brazilian Health Regulatory Agency (ANVISA), Aeronautical Command (COMAER) and airlines in order to inspect, supervise and implement preventive measures, identify possible suspected cases and organize air routes should an airport close momentarily. INFREAERO and other airport administrators were responsible for coordinating measures enforcement in airports together with ANAC and ANVISA. It was incumbent on ANVISA the enforcement, surveillance and inspection of public health and hygiene procedures to be taken. The 
measures adopted by ANVISA following the WHO declaration of PHEIC can be broken down in three main areas of action: (1) control and monitoring of flights from North America mainly by passenger screening and (2) communication, namely audible warnings and reports on airports and airplanes about symptoms and procedures, as well as the distribution of fliers with information concerning H1N1. One month after the first actions were taken, ANVISA also demanded arriving travelers to fill out a Traveler Health Declaration.

Differently from the H1N1 outbreak, travel restrictions were applied by the Brazilian Government during the COVID-19 pandemic. On March 23 ${ }^{\text {rd }}$, 2020, ordinance №133 prohibited foreigners from the following countries from entering Brazil for a period of 30 days, regardless of their nationality: China, European Union, Iceland, Norway, Switzerland, United Kingdom, Northern Ireland, Australia, Iran, Japan, Malaysia and Korea Republic. On April 28 ${ }^{\text {th }}, 2020$, ordinance №203 prohibited foreigners from all countries from entering Brazil for a period of 30 days, regardless of their nationality.

Throughout the pandemic, ANVISA issued several technical notes concerning the appropriate sanitary measures to be taken in airports and aircraft in order to cope with the outbreak of COVID-19. Technical note $\mathrm{n}^{\circ} 38$, from March $25^{\text {th }}, 2020$, whose content would later be updated by technical note no 101, informed the actions that the agency would be conducting, which were (1) to observe WHO's guidelines, (2) assure sanitary vigilance at São Paulo Guarulhos Intl. Airport, (3) institute a 24-hour watch for sanitary vigilance at international airports with nightly operation and (4) intensify the vigilance of suspected cases at airports. This technical note also addressed measures that airport administrators and airlines should comply with. On technical note $\mathrm{n}^{0} \mathbf{1 0 1}$, it became clear that what was an impending threat erstwhile had developed into community transmission, and thus demanded ANVISA to cover and inspect all flights, domestic and international, at international airports. (ANVISA, 2020)

Audible warnings were provided by ANVISA to airports and airlines, all of which had versions in Portuguese, English and Spanish. Technical note ํo 101 supplied the following three speeches to be played at airports: 
Speech 1:

Due to the new coronavirus public health emergency, Anvisa reinforces the need to adhere to social distancing and isolation measures. This recommendation applies to everybody irrespective of travel history to foreign countries. Pay attention to the recommendations issued by the Ministry of Health, Anvisa, and local governments through official communication channels. The use of face mask is recommended when going out.

Speech 2:

Anvisa Alert: Be aware of possible signs and symptoms of COVID-19. If you have mild symptoms, stay at home for 14 days. If you have difficulty in breathing, seek the nearest hospital.

Speech 3:

Anvisa Alert: To protect your health from the new coronavirus, follow simple steps: Wash your hands frequently with soap and water. Use an alcohol-based hand sanitizer if soap and water are not available. Cover your nose and your mouth with a disposable tissue when coughing or sneezing. Discard the tissue in the trash and wash your hands. Avoid agglomerations and closed places, keeping them ventilated. Do not share personal belongings such as cutlery, plates, glasses or bottles. (ANVISA, 2020, p. 16) 
Figure 3 - Airports were advised by ANVISA to take the following measures

\section{Airports were advised by ANVISA to take the following measures:}

Display the audible warnings;

Notify the sanitary authority of any suspected cases identified at the airport area;

Post on their websites that should only head to the airport terminal those persons who will actually get on a flight;

keep an updated schedule of arrivals and departures, especially of repatriation flights;

Supervise the cleaning personnel as to the intensification of their procedures;

Demand that workers and travelers wear face masks;

Organize the circulation of people so as to respect the two-meter distance recommendation, either in queues or in waiting rooms;

Place hand sanitizer dispensers in the terminal;

Stick information material regarding prevention measures near at-risk locations, such as elevators, restrooms, food courts and drinking fountains;

Ensure that bathrooms are supplied with liquid soap and running water for proper sanitation of hands;

Update the contingency plans;

keep tables two meters away from one another at food courts;

Transport the passenger from or to the remote area in vehicles with no more than half its nominal capacity:

Keep the central air-conditioning system running provided that air renewal is open with maximum capacity. On locations where air renewal is not possible, it's advisable to keep windows and doors open; and

Ensure that the Maintenance, Operation and Control Plan of air conditioning systems are enforced.

Source: The Authors (2021).

RC: 99838

Available in: https://www.nucleodoconhecimento.com.br/health/regulatory-agencies 


\section{Airlines were instructed by ANVISA to take the following actions:}

Display the audible warnings;

Supervise the aircraft cleaning staff as to the intensification of their procedures, focusing on appropriate sanitizing, concentration, contact time, cleaning technique used and disinfection of critical areas in the aircraft, such as the galleys, bathrooms, overhead bins, among others;

Equipment with compressed air should not be used in the cleaning process of airplanes;

Seat pockets should remain empty throughout the whole public health emergency period. Exception can be made for safety cards containing cleaning instructions for the procedures that must be carried out on every stopover or connection;

Require crew members to wear face masks;

Aircraft should undergo cleaning processes on each stopover prior to the boarding of passengers;

Passenger disembarkation should be carried out by row, from the forward to the rear part of the aircraft;

Organize check-in and boarding procedures so as to respect the two-meter distance recommendation;

Whenever possible, airlines should arrange the passengers in a way that they sit away from one another;

Provide liquid soap, running water, paper towel and $70 \%$-alcohol-hand sanitizer inside the aircraft. $70 \%$-alcohol-hand sanitizer should also be available near the doors and bathrooms;

From the moment the cabin doors are closed, the aircraft air-conditioning system should be selected on the no-recirculation mode, whenever possible;

Airlines should be cautious with objects for personal use, like pillows, blankets and headphones;

In-flight services should be suspended on domestic flights. if not suspended, airlines should prioritize foods and beverages in individual packages that have already been sanitized beforehand;

In flights with suspected cases, objects for personal use from the seats located on the same row, two rows in front and two rows behind the suspected passenger must be sent directly to a laundromat for

Comply with the traveler and crew members' list solicitations, aiming to investigate any suspected cases and their contacts;

The captains of all international flights should hand the passenger manifest to the sanitary authority in the airport; and

Support the actions of communication, inspection and enforcement of sanitary control measures required by the ANVISA state units.

Source: The Authors (2021). 
ANVISA also warns that it has been observed in previous outbreaks of communicable diseases that (1) the risk of transmission is reduced when there is air renewal in the cabin interior, (2) the risk of contamination on board of an aircraft is connected to the flight time, so that longer flights increase the risk and (3) the risk of contamination between passengers on board of an aircraft is increased when the aircraft remains on the ground for an extended period of time with the air renewal system inoperative.

Brazilian agencies have been focused on enforcing sanitary protocols in airports and airplanes since day one, as well as inspecting the compliance to them. The dissemination control of a certain communicable disease goes far beyond the sanitary protocols on ports of entry; fighting a pandemic is a governmental and societal responsibility. It takes a whole nation, from top to bottom, to achieve success in this appalling pandemic struggle.

\subsection{WHAT HAS BEEN DONE AS A PRECAUTIONARY MEASURE AND/OR IMPROVED IN ORDER TO FACE FUTURE PANDEMICS?}

COVID-19 has been a true test to the aviation and public health sectors on so many levels. On March 26 ${ }^{\text {th }}, 2020$, COVID-19 had already killed more people than H1N1 did in total - staggering numbers that show how brutal a virus the world is dealing with. Even though it is a far-sighted move to project the sector's preparedness for a future pandemic, it is imperative to point out that the current coronavirus pandemic is far from over, meaning that adjustments regarding this outbreak are still bound to happen.

Financially speaking, pandemics can leave grim scars on the aviation field for years to come. Like terrorist attacks or economic crises, the best way to be financially prepared for a pandemic is to keep an austere economic policy and to have ways of safeguarding the company during troubling times. Amid a pandemic, government assistance and other sorts of agreements are feasible ways to battle the crisis, and are often urged by international organizations, such as ACI and IATA. 
With regard to the sanitary aspect, the process of aircraft cleaning has certainly been improved. The protocols airlines had to follow for an extended period of time contribute to sharpen the cleanse of airplanes and airports.

One essential instrument that will be used in future pandemics is the online tools and portals that gather information and redirect the user to the proper websites. CAPSCA has been of great assistance, uniting in one page all sorts of useful documents and updates concerning any disease outbreaks that may affect the aviation sector.

As said before, there is no scale or technique that can measure the preparedness of the aviation and public health sectors for the next pandemic. Notwithstanding the uneasiness to be as prepared as possible, the guidelines and the various response plans are all there, sorted out and available to be followed. The world is not unprepared when it comes to assistance by means of guidance and protocols, although this is just part of the equation - when a pandemic strikes, it is noticeable that the ultimate form of action rests with national governments and their agencies. Therefore, there can be as many available guidelines as possible and there are still going to be several underdeveloped countries with alarming infrastructure problems that will not be completely able to adhere to them. Moreover, it should be said that notwithstanding the few resources some countries might have, the seriousness which the pandemic is dealt with is a critical and paramount factor. Being resourceful can be pointless if the disease outbreak is underestimated. The risk is serious, and the threat is real; therefore, a pandemic should not be downplayed whatsoever. Suffice to say that being ready for a pandemic is more than a matter of having guidelines and preparedness plans; it is a socioeconomic and geopolitical issue.

\section{FINAL CONSIDERATIONS}

This paper intended to carry out a historical retrospective of an entire decade, starting with the H1N1 outbreak and ending with the ongoing COVID-19 pandemic. To this end, special attention was given to the existing preparedness plans that were arranged before, during and after those outbreaks. They are not entrenched documents, in that they are constantly being refined with the most accurate 
information possible. This article also meant to study the several guidelines and other guidance packs that are provided during these sanitary crises. Most of them are available online, which was helpful so as to find and read them. A positive point that ought to be made is that these guidelines are well-organized on the websites - they are often easy to find. Some websites are better than others, with better arrangement and organization as well as an enhanced server. CAPSCA website was extremely helpful, redirecting to the pages of the various organizations involved in such a crisis.

The qualitative research was the best, most feasible way to evaluate what had been proposed as the subject of study. The analysis mainly consisted of a thorough reading of the documents available online, which were enough to ideate a viewpoint regarding the preparedness of both public health and aviation sectors for a pandemic.

However, it should be noted that, amongst the challenges faced in writing this article is the unavailability to read or access some resources, like specialized journals or articles. We are also aware that, ultimately, medicine and biology academics could speak with higher authority regarding the biological aspects of this research, although this facet was carefully read about.

Disease outbreaks can have a roiling effect in a society in a matter of weeks, if not days, and the aviation sector has got to acknowledge that it plays a fundamental part in preventing a certain communicable disease from becoming unbridled. Managing the international spread of a disease is an effort that should be spearheaded by international organizations and the countries' national agencies, in combination with not only the aviation sector representatives, but also other parts that may be involved in disseminating the infection. Until mass immunization is not attained by means of reliable vaccine, countries are subject to be hit repeatedly by waves of infection, wherein travel restrictions as well as other containment measures may once again come into effect. Although months of facing COVID-19 can most definitely provide a whole new level of enhanced preparedness, it can, paradoxically, lessen the adherence by losing its newness characteristic, in addition to the population's weariness to the various restrictions imposed. It can't be stressed enough that all 
citizens should be conscious and aware of their responsibilities as well, following closely the orientations that the public health authorities emit.

\section{REFERENCES}

$\mathrm{ACl}$. Airports Council International. Airport preparedness guidelines for outbreaks of communicable disease, 2020. Available on: https://aci.aero/wpcontent/uploads/2020/01/Airport_preparedness_guidelines_for_outbreaks_of_comm unicable.pdf. Access on: June 9 $9^{\text {th }}, 2020$.

ANVISA. Agência Nacional de Vigilância Sanitária. Nota técnica no 38/2020/SEI/COSAN/GHCOS/DIRE3/ANVISA https://www.gov.br/anvisa/ptbr/arquivos-noticias-anvisa/512json-file-1 Access on: October 10 $0^{\text {th }}, 2020$.

ANVISA. Agência Nacional de Vigilância Sanitária. Nota técnica no 101/2020/SEI/GIMTV/GGPAF/DIRE5/ANVISA

Available on: https://www2.camara.leg.br/atividade-legislativa/comissoes/comissoestemporarias/externas/56a-legislatura/enfrentamento-pandemia-covid-19/outrosdocumentos/documentos-encaminhadospelacomissao/Anexo_4396144_Nota_Tecnica_101__Aeroporto_anvisa.pdf. Access on: October $10^{\text {th }}, 2020$.

ANVISA. Agência Nacional de Vigilância Sanitária . Nota técnica no 62/2020/SEI/GIMTV/GGPAF/DIRE5/ANVISA. Available on: https://www.resgateaeromedico.com.br/wp-content/uploads/2020/04/SEI_ANVISA0970582-Nota-Te\%CC\%81 cnica-Aeroportos.pdf. Access on: October 10th, 2020.

BAIG, Abdul Mannan et al. Evidence of the COVID-19 virus targeting the CNS: tissue distribution, host-virus interaction, and proposed neurotropic mechanisms. ACS Chemical Neuroscience, n. 11, p. 995-998, 2020.

BOWEN JUNIOR, John T; LAROE, Christian. Airline networks and the international diffusion of severe acute respiratory syndrome (SARS). The Geographical Journal, v. 172, n. 2, p. 130-144, jun. 2006. 
BUDD, Lucy; BELL, Morgan; BROWN, Tim. Of plagues, planes and politics: controlling the global spread of infectious diseases by air. Political Geography, n. 28 , p. 426-435, 2009.

CDC. Centers for Disease Control and Prevention. 2009 H1N1: overview of a pandemic. Available on: https://www.cdc.gov/h1n1flu/yearinreview/yir5.htm. Access on: May $10^{\text {th }}, 2020$.

CDC. Centers for Disease Control and Prevention. History of the 1918 flu pandemic, 2019. Available on: https://www.cdc.gov/flu/pandemic-resources/1918commemoration/1918-pandemic-history.htm. Access on May $5^{\text {th }}, 2020$.

COSSAR, Jonathan $\mathrm{H}$. Influence of travel and disease: an historical perspective. Journal of Travel Medicine, v. 1, n. 1, p. 36-94, 1994.

COX, N. J; SUBBARAO, K. Global epidemiology of influenza: past and present. Annual Review of Medicine, n. 51, p. 407-421, 2000.

CSSE. Center for Systems Science and Engineering. COVID-19: dashboard at John Hopkins University (JHU). John Hopkins University, Baltimore, Maryland. Available on: https://coronavirus.jhu.edu/map.html. Access on: May $5^{\text {th }}, 2020$.

DEWITTE, Sharon N. Mortality risk and survival in the aftermath of the medieval black death. Department of Anthropology, University of South Carolina, Columbia, South Carolina, 2014.

ECDC. European Centre for Disease Prevention and Control. COVID-19 situation update worldwide, as of week 7, updated 24 February 2021. Available on: https://www.ecdc.europa.eu/en/geographical-distribution-2019-ncov-cases. Access on: Feb. 24, 2021.

FERRELL, Chelsea; AGARWAL, Pulkit. Flight bans and the Ebola crisis. Harvard Public Health Review. Fall, 2018;14. 
FINDLATER, Aidan; BOGOCH, Isaac I. Human mobility and the global spread of infectious diseases: a focus on air travel. Trends in Parasitology, v. 34, n. 9, Sep/2018.

FISCHER, Marc; STAPLES, Erin. Chikungunya virus spreads in the Americas: Caribbean and South America, 2013-2014. MMWR, v. 63, n. 22, June 6, 2014.

FLIGHTRADAR 24. 2019 by the numbers. Available on: https://www.flightradar24.com/blog/flightradar24s-2019-by-the-numbers/. Access on: Feb. 24, 2021.

GAO, Yan et al. Structure of the RNA-dependent RNA polymerase from COVID-19 virus. Science, v. 368, n. 6492, p. 779-782, May 15, 2020.

HELMS, Henrique. A aviação como vetor de disseminação de enfermidades: as doenças que vêm voando. Orientador: Claudia Musa Fay. 2018. 192 f. Tese (Doutorado em História)-Pontifícia Universidade Católica do Rio Grande do Sul, Programa de Pós-graduação em História, Porto Alegre, 2018.

ICAO. International Civil Aviation Organization. ICAO drives contingency plans for aviation sector. Montreal, May $20^{\text {th }}, 2009$.

ICAO. International Civil Aviation Organization. ICAO-WHO CAPSCA Global Symposium, 2015.2 Available on: https://www.icao.int/Meetings/CAPSCA2015/Pages/default.aspx. Access on: May $12^{\text {th }}, 2020$.

ICAO. International Civil Aviation Organization. Member states. 2019. Available on: https://www.icao.int/about-icao/pages/member-states.aspx. Access on: October $5^{\text {th }}$, 2020.

INGOLD, Tim. Companion encyclopedia of anthropology. Routledge: Oxford, 1994. 
ISIDORE, Chris. Airlines will offer fewer choices and higher fares after the coronavirus crisis. CNN Business, Apr. 1 1st, 2020. Available on: https://edition.cnn.com/2020/04/01/business/airline-industry-outlook/index.html. Access on:

JILANI, Talha N.; JAMIL, Radia T.; SIDDIQUI, Abdul H. H1N1 Influenza (Swine Flu). In: StatPearls. Treasure Island (FL): StatPearls Publishing; 2020.

KHAN, Kamran et al. Entry and exit screening of airline travellers during the $A(H 1 N 1)$ 2009 pandemic: a retrospective evaluation. Bulletin of the World Health Organization 2013, n. 91, p. 368-376, 2013.

KOLIFARHOOD, Goodarz et al. Epidemiological and clinical aspects of COVID-19: a narrative review. Archives of Academic Emergency Medicine (AAEM), v. 8, n. 1, e41, 2020.

LAU, Chih-Cheng et al. Severe acute respiratory syndrome coronavirus 2 (SARSCoV-2) and coronavirus disease-2019 (COVID-19): the epidemic and the challenges. International Journal of Antimicrobial Agents, v. 55, n. 3, p. 105924, Mar. 2020.

NISHIURA, Hiroshi; KAMIYA, Kasuko. Fever screening during the influenza (H1N12009) pandemic at Narita International Airport, Japan. BMC Infectious Diseases, $201111: 111$.

PAHO. Pan American Health Organization. Infecções por coronavírus. Disponível em: https://www.paho.org/en/topics/coronavirus-infections. Acesso em: 25 fev. 2021.

PEIRIS, J. S. Malik; POON, L. M. Leo; GUAN, Yi. Emergence of a novel swine-origin influenza A virus (S-OIV) H1N1 virus in humans. Journal of Clinical Virology, n. 45, p. 169-173, 2009 .

REZZA, Giovanni. Chikungunya is back in Italy: 2007-2017. Journal of Travel Medicine, v. 25, n. 1, tay004, 2018. 
TATEM, Andrew J.; ROGERS, David J.; HAY, Simon lain. Global transport networks and infectious disease spread. Advances in Parasitology, v. 62, p. 293-343, 2006.

TAUBENBERGER, Jeffery K.; REID, Ann H.; JANCZEWSKI, Thomas A.; FANNING, Thomas G. Integrating historical, clinical and molecular genetic data in order to explain the origin and virulence of the 1918 Spanish influenza virus. Philosophical Transactions of The Royal Society of London: Series B, Biological Sciences, v. 356, n. 1416, p. 1829-1839, 2001.

TAUBENBERGER, Jeffery K. The origin and virulence of the 1918 "Spanish" influenza virus. Proceedings of the American Philosophical Society, v. 150, n. 1, p. 86-112, 2006.

THOMPSON, Derek. The pandemic will change american retail forever. The Atlantic, Apr. 2020. Available on: https://www.theatlantic.com/ideas/archive/2020/04/how-pandemic-will-change-faceretail/610738/. Access on: Feb. 24, 2021.

TRIMBLE, Ashleigh; MOFFAT, Viva R.; COLLINS, Andrea M. Pulmonary infections in the returned traveller. Pneumonia, n. 9, p. 1, 2017.

TONG, Suxiang; ZHU, Xueyong; LI, Yang; SHI, Mang; ZHANG, Jing et al. New world bats harbor diverse influenza A viruses. PLOS Pathogen, v. 9, n. 10, e1003657, 2013.

VELAVAN, Thirumalaisamy P.; MEYER, Christian G. The COVID-19 epidemic. Tropical Medicine and International Health, v. 25, n. 3, p. 278-280, March 2020.

VIENNA convention on the law of treaties. United Nations International Law Commission. Vienna, Austria, 1969.

WHO AFRICA. Coronavirus. Available https://www.afro.who.int/publications/coronavirus. Access on: Feb. 24, 2021. 
WHO. World Health Organization. Pandemic (H1N1) 2009 - update 94. Available on: https://www.who.int/csr/don/2010_04_01/en/. Access on May 10 ${ }^{\text {th }}, 2020$.

WHO. World Health Organization. Pandemic Influenza A (H1N1): donor report 1, March $2011 . \quad$ Available on: https://www.who.int/csr/resources/publications/swineflu/h1n1_donor_032011.pdf. Access on: May $12^{\text {th }}, 2020$.

WHO. World Health Organization. Pandemic influenza preparedness and response: a WHO guidance document, 2009. Available on: https://www.ncbi.nlm.nih.gov/books/NBK143062/pdf/Bookshelf_NBK143062.pdf. Access on: May $12^{\text {th }}, 2020$.

WHO. World Health Organization. Q\&A Influenza and COVID-19: similarities and differences. Available on: https://www.who.int/emergencies/diseases/novelcoronavirus-2019/question-and-answers-hub/q-a-detail/q-a-similarities-anddifferences-COVID-19-andinfluenza?gclid=EAlalQobChMlvr2P_aKq6QIVCAyRCh3fzQ5EAAYASAAEgJRLvD_BwE. Access on: May 14th 2020.

WHO. World Health Organization. Rolling updates on coronavirus disease (COVID-19). Available on: https://www.who.int/emergencies/diseases/novelcoronavirus-2019/events-as-they-happen. Access on May $10^{\text {th }}, 2020$.

WHO. World Health Organization. WHO Summary of probable SARS cases with onset of illness from 1 November 2002 to 31 July 2003. Available on: https://www.who.int/csr/sars/country/table2004_04_21/en/. Access on May 5 ${ }^{\text {th }}, 2020$.

Posted: June, 2021.

Approved: October, 2021. 